\title{
DIETARY INTAKES, PHYSICAL ACTIVITY, AND PREDICTORS OF CHILD OBESITY AMONG 4-6th GRADERS IN THE CZECH REPUBLIC
}

\author{
Lenka Humeníková, Gail E. Gates \\ Department of Nutritional Sciences at Oklahoma State University (OSU), Stillwater, OK, USA
}

\begin{abstract}
SUMMARY
The prevalence of child obesity in the Czech Republic has increased in the last several years, especially among school-aged children. While obesity trends are closely monitored in the Czech Republic, very little is known about the dietary habits and exercise behaviors of Czech children. The purpose of this study was to evaluate nutrient intakes and physical activity, as well as identify predictors of BMI-for-age in a sample of Czech school-aged children. Ninety-seven fourth, fifth and sixth graders and their parents from two large Czech cities participated in the study. Two 24-hour recalls provided total amount of energy, fat, percentage of energy derived from fat, dietary fiber, and servings of fruits and vegetables. Physical activity was measured by the Self-administered Physical Activity Checklist (SAPAC). Children consumed less energy and dietary fiber than suggested by Czech dietary recommendations. The proportion of energy that children consumed from fat was $28.5 \%$. Children consumed 1.4 cups of fruit and 1.2 cups of vegetables. Children's physical activity levels fell within the current recommendations. Age was the only significant predictor of higher BMI-for-age. Poor dietary quality may be responsible for increasing rates of child obesity in the Czech Republic. Nutritional professionals in the Czech Republic should focus on increasing consumption of fruits, vegetables, and other high-fiber foods in order to reduce the risk for overweight among Czech children.
\end{abstract}

Key words: child obesity, Czech Republic, dietary habits, physical activity, BMl-for-age

Address for correspondence: L. Humeníková, 417 HES, Department of Nutritional Sciences, Oklahoma State University, Stillwater, OK 74078. E-mail: lenka.humenikova@okstate.edu

\section{INTRODUCTION}

Child obesity has become a serious public health problem in many developed countries over the last several decades (1). The recent increases in child obesity rates are alarming because studies demonstrated that the majority of overweight children remain overweight or obese in their adult years (2-4). It is estimated that up to $40 \%$ of 7 -year-old and $80 \%$ of 10 to 15 -year-old obese children remain obese as adults, which substantially increases their risk of developing a chronic disease (2-5). Previous research identified a wide range of factors that may be contributing to increased body weight and adiposity among children. Excessive intakes of energy and fat, increased consumption of sweetened beverages, and low intakes of fruits and vegetables are often associated with higher Body Mass Indexes (BMI) among young children (6, 7). Lack of physical activity and increased sedentary behaviors have also been linked to child obesity (7). In fact, physical inactivity has been identified as one of the strongest correlates of child obesity, with television watching being linked to decreased energy expenditure and increased appetite among children (8). Because children develop their dietary habits and exercise behaviors early in life, parents play a crucial role in the reduction and prevention of obesity (9). The strong influence of parents on children's food choices within the family environment is reflected in the fact that high parental BMI, low parental education, and lack of available healthy foods in the home were found to be strongly associated with obesity among children in several countries $(10,11)$.
While the United States has one of the highest rates of overweight among children in the world (22\% overweight) (12), a trend toward increased obesity rates has been observed among children in several European countries (10, 13). For example, Kromeyer-Hauschild et al. (14) found that the proportion of overweight German girls increased from $11.7 \%$ in 1975 to $20.7 \%$ in 1995 . The prevalence of obesity among children from Central and Eastern European countries, including the former Czechoslovakia, is generally lower than the U.S. and Western Europe (15). However, recent findings from the Czech Republic suggest that the proportion of overweight and obese children has recently increased (16).

Findings from the 1991 and 2001 Czech National Anthropological Surveys revealed that child obesity rates increased in the age group that is most predictive of adult adiposity (ages 7-11). In 1991, 3\% of Czech children were obese; by 2001, 5.6\% of boys and $4.7 \%$ of girls were obese (16). A 1999-2000 study measured 7 to 11 year old children in 38 public schools in the Czech Republic (17). The findings revealed that $13.1 \%$ of boys and $11.9 \%$ of girls were overweight or obese in 1999 compared to $10 \%$ in 1991 (17). These studies provide evidence that, despite relatively low child obesity rates in relation to other countries, the prevalence of overweight and obesity is rising among elementary school-aged Czech children.

The Czech traditional diet is characterized by large amounts of meat and saturated fats, and by lower amounts of fruits and vegetables (18). Czech 10-year-old children were found to con- 
sume almost $35 \%$ of energy from fat while adolescents' intakes of vitamin C, vitamin A and calcium were below the recommended amounts $(19,20)$. The nutritional status of Czech children has also been influenced by significant economic and social changes in the last several years. While the influx of Western culture has brought several positive nutritional trends into the country, children are increasingly exposed to negative dietary and lifestyle trends, such as an increase in fast food consumption and a decrease in physical activity $(20,21)$

While obesity rates among Czech children have been closely monitored in the last several decades, there is very limited knowledge about the dietary habits and physical activity of Czech school-aged children (20). Understanding important predictors of obesity is crucial for developing comprehensive and effective obesity prevention programs for Czech children. The purposes of our study were to determine dietary intakes in terms of energy, fat, and fiber intakes, and fruit and vegetable servings; evaluate the amount and intensity of physical activity; and identify important predictors of BMI in a sample of Czech fourth, fifth and sixth grade children.

\section{MATERIAL AND METHODS}

The study was based on a cross-sectional, correlational study, with a pilot study conducted one year prior to data collection. The target population was elementary school children in grades four, five, and six in two Czech cities (Pilsen and Prague). The schools were randomly selected using a cluster sampling technique and one school in Prague was selected using convenience sampling. Sample size estimation was based on $\mathrm{R}^{2}$ of 0.3 and power of 0.8 using ten independent variables in a regression model at $\mathrm{p}=0.05$ (22). The study was approved by the Institutional Review Board at Oklahoma State University and the Ethical Institute of Charles University in Prague, Czech Republic.

Informed written consent was obtained from the principals at each of the selected schools. Parents were informed about the study during a parent meeting or a detailed description of the study was sent home through their children. The parents who agreed to participate were asked to sign written consent and complete the Parent Questionnaire. The questionnaire requested demographic, socioeconomic, and anthropometric information. Self-reported height and weight of parents were used to calculate parental BMI as $\mathrm{kg} / \mathrm{m}^{2}$ (overweight: BMI of $\geq 25$; obese: BMI of $\geq 30$ ). Monthly household income (in Czech Crowns) was reported by parents in five categories: $\leq 10,000,11,000-20,000$, 20,000-30,000, 30,000-40,000, and $>40,000$. Parents reported education level in four categories: elementary, vocational, highschool, and university education.

Two school visits, at least two days apart, were scheduled with children. Children were asked for assent to take part in the study prior to data collection. Information collected from children included demographics, height, weight, dietary intakes and physical activity. Children completed one multiple-pass 24-hour recall (23) and a modified Self-administered Physical Activity Checklist (SAPAC) (24) with the help of the primary investigator or a research assistant. The use of a 24-hour recall was shown to be a valid method of estimating energy and macronutrient intakes of children aged 8 and older in previous research (25). Plastic food models, real food examples, bean bags and household measuring tools were used to improve the quality of the 24-hour recall.

Dietary intakes were analyzed using the nutrient analysis software Food Processor 8.4. Children's energy, fat, and fiber intakes were estimated as 2-day averages of kilocalories, grams of fat, percentage of energy from fat, and grams of dietary fiber. The average numbers of cups of fruits and vegetables were estimated using the MyPyramid of the United States Department of Agriculture (26). A calculation of fruit and vegetable servings based on the Food Guide Pyramid was shown to be a valid measure of children's fruit and vegetable intake in previous studies (27). Because the original dietary recommendations for children in the Czech Republic have not been updated since late 1980's, children's intakes were compared to the MyPyramid recommendations in addition to the Czech dietary standards (28). The children's intakes were compared to the MyPyramid recommendations based on their age, gender and physical activity level. Dietary fiber intakes were compared to the Adequate Intake for children aged 9 to 13 (29).

Children were also asked to recall the activities they engaged in on the previous day using the modified SAPAC (24). The SAPAC has been validated in previous studies that showed its moderate correlation with both heart rate index and accelerometer scores (24). The original SAPAC was self-administered and included a total of 25 physical activities and two sedentary activities. The questionnaire was administered by the investigators in order to increase the accuracy and validity of the collected data.

Metabolic equivalents (METs) were assigned to all of the physical activities reported by children based on the updated Compendium of Physical Activities developed by Ainsworth et al. (30). One metabolic equivalent is defined as the ratio of the work metabolic rate to the resting metabolic rate, which is equal to the amount of oxygen per kilogram of body weight per minutes that is consumed when sitting quietly $(3.5 \mathrm{ml} / \mathrm{kg} / \mathrm{min}$ or $1 \mathrm{kcal} / \mathrm{kg} /$ hour) (30). Moderate activity was defined as any physical activity during which children expended 3-6 METs and vigorous activity was defined as any activity with METs of greater than 6 (30). A two-day average of estimated METs, the average number of minutes spent in moderate and vigorous activities, and the amount of time spent in moderate and vigorous activity combined was estimated for each child.

The height and weight of children were measured in the morning hours at each school. Weight was measured using an electronic scale (Taylor Precision Performance, Oak Brook, Illinois, USA) with a stable weighing platform. Height was measured using the Frankfort Plane technique while their head, back, and buttocks touched a vertical wall behind them. Height and weight measurements were used to calculate children's BMI as $\mathrm{kg} / \mathrm{m}^{2}$. The prevalence of overweight was assessed using the 1991 Czech reference values (31). Children were classified as underweight ( $<10$ th percentile), normal weight (10-90th percentile), overweight ( $>90$ th percentile), or obese ( $>97$ th percentile). The 2000 CDC reference values were used to identify children at risk for overweight by BMI-for-age of $\geq 85$ th to $<95$ th percentile, and overweight children by BMI-for-age of $>95$ th percentile (32). Z-scores that represent the deviations of the value for an individual child from the mean value of the reference population divided by the standard deviation were also calculated using the statistical package Epi Info 2005. 
One sample t-tests, independent t-tests, $\chi$-square test, bivariate correlation and a linear regression model were used to analyze children's dietary intakes and physical activity, and to identify significant predictors of their BMI. Parental BMI, education, income, children's age, energy intake, percent energy from fat, time (minutes) spent in moderate and vigorous activity, and fruit and vegetable intake were included in the model as independent variables. The Statistical Package for Social Sciences (SPSS 12.0, 2003) was used to conduct statistical analysis in this study. The level of significance was set at 0.05 .

\section{RESULTS}

Ninety seven children and their parents participated in the study. The descriptive characteristics of the subjects are summarized in Table 1. The mean parental BMI of $22.8 \pm 3.9$ fell within a healthy range which is defined by internationally recognized standards as BMI of 18.5 to 24.99. The prevalence of overweight and obesity among children using the Czech reference cutoffs and the 2000 CDC reference cutoffs is presented in Table 2. Four children in the sample were identified as obese using both the Czech standards and the 2000 CDC cutoff values (Table 2). The overall prevalence of overweight and obesity in the sample

Table 1. Demographic and anthropometric characteristics of parents and children

\begin{tabular}{|c|c|c|c|c|}
\hline \multicolumn{2}{|l|}{ Category } & $\mathrm{n}$ & $\%$ & Mean + SD \\
\hline \multicolumn{5}{|l|}{ Children } \\
\hline \multicolumn{2}{|l|}{ Age (years) } & 97 & 100.0 & $11.0 \pm 1.03$ \\
\hline \multicolumn{2}{|l|}{ BMl $\left(\mathrm{kg} / \mathrm{m}^{2}\right)$} & 95 & 95.0 & $18.4 \pm 2.52$ \\
\hline \multirow{3}{*}{ Grade } & 4th grade & 27 & 28.0 & - \\
\hline & 5th grade & 43 & 44.0 & - \\
\hline & \begin{tabular}{|l|}
6 th grade \\
\end{tabular} & 27 & 28.0 & - \\
\hline \multirow{2}{*}{ Gender } & Males & 42 & 43.0 & - \\
\hline & Females & 55 & 57.0 & - \\
\hline \multicolumn{5}{|l|}{ Parents } \\
\hline \multicolumn{2}{|l|}{ Age (years) } & 92 & 95.0 & $37.3 \pm 5.25$ \\
\hline \multirow{2}{*}{ Gender } & Males & 4 & 4.0 & - \\
\hline & Females & 94 & 96.0 & - \\
\hline \multirow[t]{5}{*}{$\operatorname{BMI}\left(\mathrm{kg} / \mathrm{m}^{2}\right)$} & & 92 & 95.0 & $22.8 \pm 3.48$ \\
\hline & $<18.5$ & 5 & 5.2 & - \\
\hline & $18.5-24.99$ & 66 & 68.0 & - \\
\hline & $25-29.99$ & 18 & 18.6 & - \\
\hline & $>30$ & 3 & 3.1 & - \\
\hline \multirow{4}{*}{ Education } & elementary & 0 & 0.0 & - \\
\hline & vocational & 20 & 20.6 & - \\
\hline & high-school & 55 & 56.7 & - \\
\hline & university & 18 & 18.6 & - \\
\hline \multirow{5}{*}{ Monthly income } & $<10,000$ & 2 & 2.1 & - \\
\hline & $11,000-20,000$ & 36 & 37.1 & - \\
\hline & $20,000-30,000$ & 28 & 28.9 & - \\
\hline & $30,000-40,000$ & 15 & 15.5 & - \\
\hline & $>40,000$ & 6 & 6.2 & - \\
\hline
\end{tabular}

Table 2. Child obesity prevalence as defined by the 2000 CDC and the Czech reference values

\begin{tabular}{|c|c|c|}
\hline \multirow[t]{2}{*}{ Reference Values } & \multicolumn{2}{|c|}{ Obesity Prevalence } \\
\hline & $\mathrm{n}$ & $\%$ \\
\hline \multicolumn{3}{|l|}{2000 CDC Reference Values ${ }^{1}$} \\
\hline $\begin{array}{c}\text { At risk for overweight }(\geq 85 \text { th- }<95 \text { th percentile) } \\
\text { Males } \\
\text { Females }\end{array}$ & $\begin{array}{r}10 \\
5 \\
5\end{array}$ & $\begin{array}{r}10.3 \\
11.9 \\
9.1\end{array}$ \\
\hline $\begin{array}{l}\text { Overweight ( } \geq 95 \text { th percentile) } \\
\qquad \begin{array}{l}\text { Males } \\
\text { Females }\end{array}\end{array}$ & $\begin{array}{l}4 \\
2 \\
2\end{array}$ & $\begin{array}{l}4.1 \\
4.8 \\
3.6\end{array}$ \\
\hline At risk or overweight ( $\geq 85$ th percentile) & 14 & 14.4 \\
\hline \multicolumn{3}{|l|}{ Czech Reference Values $^{2}$} \\
\hline $\begin{array}{r}\text { Overweight (90th-97th percentile) } \\
\text { Males } \\
\text { Females }\end{array}$ & $\begin{array}{l}7 \\
3 \\
4\end{array}$ & $\begin{array}{l}7.2 \\
7.1 \\
7.3\end{array}$ \\
\hline $\begin{array}{l}\text { Obese (>97th percentile) } \\
\qquad \begin{array}{l}\text { Males } \\
\text { Females }\end{array}\end{array}$ & $\begin{array}{l}4 \\
2 \\
2\end{array}$ & $\begin{array}{l}4.1 \\
4.8 \\
3.6\end{array}$ \\
\hline Overweight or obese (>90th percentile) & 11 & 11.3 \\
\hline
\end{tabular}

${ }^{1}$ Kuczmarski et al., 2002

${ }^{2}$ Lhotská et al., 1993

was $11.3 \%$ based on the Czech standards and $14.4 \%$ based on the 2000 CDC reference values.

Gender differences in the prevalence of overweight were evident based on the CDC standards but not the Czech reference values (Table 2). While the sample size did not allow for a statistical analysis based on age groups, children aged 10 appeared to have the highest mean $\mathrm{z}$-score for BMI-for-age in the sample while 13-year-old children tended to have the lowest BMI-forage z-scores (Fig. 1).

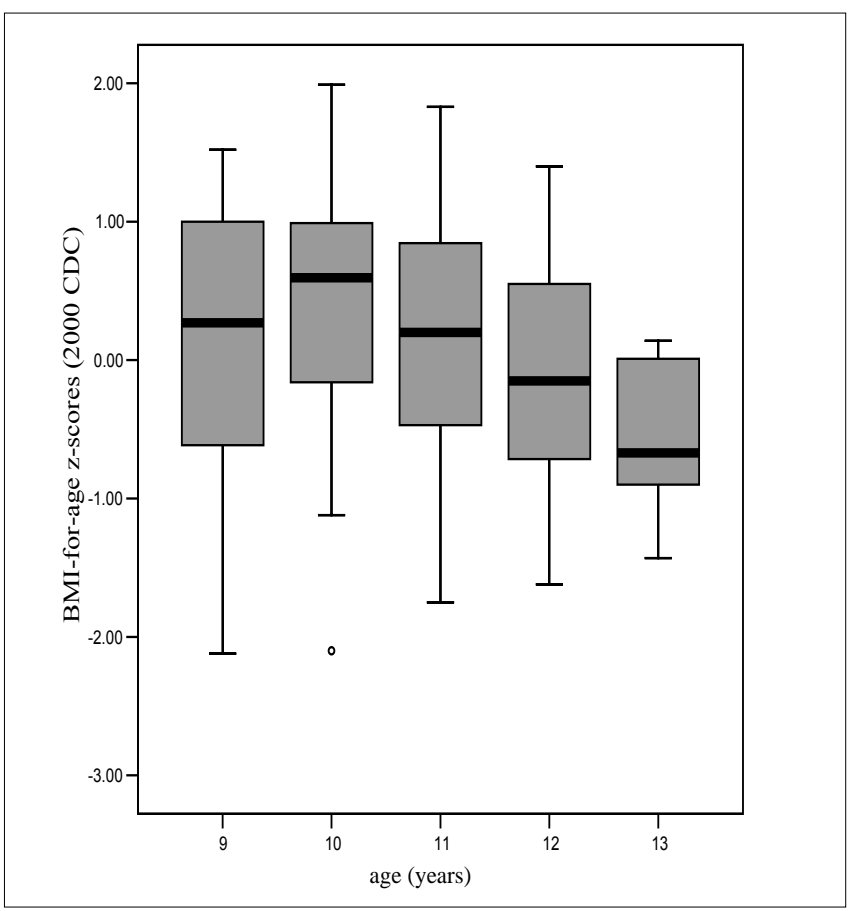

Fig. 1. Box plots of children's z-scores for BMI-for-age. 
Table 3. Differences in dietary intakes of children by gender

\begin{tabular}{|l|c|c|c|c|}
\hline & $\begin{array}{c}\text { Total } \\
(\mathbf{n}=97)\end{array}$ & $\begin{array}{c}\text { Males } \\
(\mathbf{n}=42)\end{array}$ & $\begin{array}{c}\text { Females } \\
(\mathbf{n}=55)\end{array}$ & P-value \\
\hline Energy (kcal) & $1416 \pm 374$ & $1460 \pm 403$ & $1383 \pm 350$ & 0.321 \\
\hline Fat (g) & $45.5 \pm 15.3$ & $48.8 \pm 14.4$ & $43.0 \pm 15.6$ & 0.064 \\
\hline Fat (\% energy) & $28.5 \pm 5.8$ & $30.3 \pm 5.9$ & $27.2 \pm 5.4$ & $0.009^{\star \star}$ \\
\hline $\begin{array}{l}\text { Carbohydrates } \\
\text { (\% energy) }\end{array}$ & $57.4 \pm 7.2$ & $54.9 \pm 6.9$ & $59.2 \pm 6.9$ & $0.003^{\star \star}$ \\
\hline Protein (\% energy) & $14.1 \pm 3.48$ & $14.8 \pm 3.8$ & $13.6 \pm 3.1$ & 0.090 \\
\hline Fiber (g) & $11.9 \pm 6.6$ & $10.9 \pm 3.8$ & $12.7 \pm 8.0$ & 0.164 \\
\hline Fruit (cups) & $1.4 \pm 1.1$ & $1.1 \pm 1.1$ & $1.6 \pm 1.2$ & 0.064 \\
\hline Vegetables (cups) & $1.2 \pm .9$ & $1.1 \pm .7$ & $1.3 \pm .9$ & 0.294 \\
\hline
\end{tabular}

${ }^{\star *} p<0.01$

Several trends were identified in children's diets (Table 3). Overall, children consumed $28.5 \%$ of their total daily energy from fat. Boys consumed a significantly higher proportion of energy derived from fat and girls consumed significantly more energy from carbohydrates (Table 3; $p<0.01$ ). The daily fiber intake was similar in both genders with the mean fiber intake of $11.9 \pm 6.6$ g. Children consumed approximately $1.4 \pm 1.1$ cups of fruit and $1.2 \pm 0.9$ cups of vegetables daily with no significant differences by gender (Table 3). However, girls tended to consume slightly more fruits than boys (Table $3 ; \mathrm{p}=0.064$ ).

The summary of findings related to physical activity is presented in Table 4. Children expended about $495 \pm 259$ metabolic equivalents (METs) on two days, with boys tending to be slightly more active than girls (Table 4). Children spent approximately one hour watching television and 8 minutes using a computer a day (Table 4). Most children were engaged in at least one moderate or vigorous activity on the two days. Boys engaged in vigorous activities for a significantly longer period of time than girls (Table 4).

Bivariate correlations revealed a significant negative relation between children's age and $z$-scores for BMI ( $r=-0.29$; $\mathrm{p}<0.01$ ). Children's energy intakes and their BMI z-scores tended to be negatively related $(r=-0.18 ; p=0.08)$. A linear regression model with z-scores for BMI as the dependent variable revealed that children's younger age was the only significant predictor of higher z-scores for BMI $\left(\mathrm{R}^{2}=0.144 ; \mathrm{p}<0.05\right)$. None of the parental, dietary or physical activity variables were found to be significant predictors of children's weight.

\section{DISCUSSION}

Even though the prevalence of overweight among Czech children remains lower than the rates of overweight in the U.S. and other Western countries, Czech children have been getting heavier in the last two decades $(16,17)$. Because of the negative trend in child obesity, it is essential to evaluate children's dietary intakes and physical activity and identify major factors that influence children's body weight so effective interventions can be developed for Czech children.

Our study examined current dietary intakes and physical activity behaviors in a sample of Czech fourth, fifth, and sixth
Table 4. Differences in minutes of physical activity and sedentary behaviors of children by gender

\begin{tabular}{|l|c|c|c|c|}
\hline Activity & $\begin{array}{c}\text { Total } \\
(\mathbf{n}=95)\end{array}$ & $\begin{array}{c}\text { Males } \\
(\mathbf{n}=41)\end{array}$ & $\begin{array}{c}\text { Females } \\
(\mathbf{n}=\mathbf{5 4})\end{array}$ & P-value \\
\hline Moderate & $84.8 \pm 104.9$ & $67.7 \pm 47.7$ & $97.8 \pm 132.0$ & 0.167 \\
\hline Vigorous & $23.9 \pm 36.5$ & $36.4 \pm 38.3$ & $14.5 \pm 14.7$ & $0.003^{\star *}$ \\
\hline $\begin{array}{l}\text { Moderate } \\
\text { \& vigorous }\end{array}$ & $96.7 \pm 50.7$ & $104.1 \pm 48.9$ & $91.0 \pm 51.6$ & 0.213 \\
\hline TV/DVD & $57.5 \pm 43.6$ & $62.6 \pm 42.6$ & $53.7 \pm 44.5$ & 0.327 \\
\hline Computer & $8.3 \pm 19.5$ & $14.1 \pm 26.3$ & $3.8 \pm 10.4$ & $0.009^{\star *}$ \\
\hline
\end{tabular}

${ }^{\star *} \mathrm{p}<0.01$

graders. Analysis of the 24-hour recalls revealed that most children consumed less energy than is recommended based on both the Czech and the MyPyramid dietary recommendations (26, 28). While the use of a multiple-pass 24-hour recall may have contributed to underreporting of energy and nutrient intakes among children, this finding is consistent with a study by Šoltysová and Bellisle (19) in which 10-year-old children consumed 10\% less energy than recommended by the Czech dietary standards (28). Low intakes of energy have been also observed among children from other transitional countries, such as Hungary (33). The total amount of energy derived from fat was $28.5 \%$ which was within the suggested range of $25-35 \%$ of energy from fat for children aged 4 to 18 (34). The children's relatively low dietary intake of fat in our sample may be attributed to the economic and political changes occurring in the Czech Republic since the late 1980's (20, 35). The shift from a centrally planned economy to a free market economy has caused a 300\% increase in the price of beef and even larger increases in the price of milk, which may be responsible for children consuming less fat $(20,35)$.

Children in our sample consumed only 1.4 and 1.2 cups of fruits and vegetables, which is lower than the MyPyramid recommendation for 9-year-old sedentary girls (26). Our finding was consistent with the results of several studies in other Eastern European countries. For instance, a study on dietary habits of children from Moscow revealed that they did not consume adequate amounts of fruit, fruit juice or vegetables on a regular basis (36). The children's low consumption of fruit and vegetables was also reflected in their poor intakes of dietary fiber. Compared to the Czech recommendations, that are significantly lower than the U.S. recommendations (30), the consumption of $11.9 \mathrm{~g}$ of dietary fiber was not sufficient (28). A qualitative analysis of the 24-hour recalls indicated that only a few children in the sample consumed some type of whole grain breads or cereal. Low consumption of fruits and vegetables as well as rare consumption of whole wheat breads and cereals is likely responsible for such low fiber intakes. One of the limitations of our study was related to the evaluation of children's dietary intakes. While a multiple-pass 24-hour recall was shown to be a valid method for evaluating children's dietary intakes (23), it is important to note that the analysis of children's diet was limited by the use of only two 24-hour recalls. This limitation was caused by the efforts of the investigators to minimize interference with children's instruction during the study.

Previous research showed that sedentary behaviors significantly contribute to the development of obesity among children (37). 
In our study, children watched television for about one hour and engaged in approximately 90 minutes of either moderate or vigorous physical activity a day. While no specific recommendation for physical activity for children exists in the Czech Republic, most children met and some children exceeded the recommendation of at least 60 minutes of physical activity that is recommended by the Dietary Guidelines for Americans (34).

Even though our sample of children was not nationally representative, our study was consistent with the results of a study by Kobzova et al. (16) suggesting that there is a trend towards increased obesity rates among Czech elementary school-aged children. The prevalence of both overweight and obese children combined was estimated between $11.3 \%$ and $14.4 \%$, depending on which reference values were used for the analysis. Thus, the overweight and obesity rates in our sample were higher than the prevalence of $10 \%$ that was reported in the 1991 National Anthropological Survey (31). The obesity rates alone among boys and girls were also higher compared to the 3\% obesity prevalence in 1991 (31). Boys in our study were found to be at higher risk for obesity than girls which is consistent with previous studies (16).

As child obesity rates continue to rise in the Czech Republic, it is important to carefully examine current dietary behaviors and exercise habits of children. Our findings identified important trends in the dietary intakes and physical activity of Czech schoolaged children. The role of fruits and vegetables in children's diets and their benefits in terms of obesity prevention has been emphasized in previous research. Regular intake of fruits and vegetables significantly influence satiety and energy intake which in turn may directly affect BMI of children. Despite obvious benefits of fruits and vegetables, children in the Czech Republic do not consume adequate amounts of them on a regular basis. While a future study on dietary habits and physical activity with a nationally representative sample of Czech children is warranted, our study contributes to the existing literature on Czech children's dietary intakes and physical activity. Based on the findings of our study, nutritional professionals in the Czech Republic should focus on improving the dietary habits among school-aged children and address the inadequate consumption of fruit, vegetables, and fiber in future nutrition interventions.

\section{REFERENCES}

1. World Health Organization. Diet, nutrition and the prevention of chronic diseases: report of a joint WHO/FAO expert consultation. WHO Technical report series No. 916. Geneva: WHO; 2002.

2. Webber LS, Wattingney WA, Srinivasan SR, Berenson GS. Obesity studies in Bogalusa. Am J Med Sci. 1995 Dec;310 Suppl 1:S53-61.

3. Guo SS, Roche AF, Chumlea WC, Gardner JD, Siervogel RM. The predictive value of childhood body mass index values for overweight at age 35 y. Am J Clin Nutr. 1994 Apr;59(4):810-9.

4. Whitaker RC, Wright JA, Pepe MS, Seidel KD, Dietz WH. Predicting obesity in young adulthood from childhood and parental obesity. N Eng J Med. 1997 Sep 25;337(13):869-73.

5. Stránský M. Causes and treatment of children's obesity in Switzerland. Výž Potrav. 2000;2:24-5. (In Czech.)

6. Paeratakul S, Ferdinand DP, Champagne CM, Ryan DH, Bray GA. Fastfood consumption among US adults and children: dietary and nutrient intake profile. J Am Diet Assoc. 2003 Oct;103(10):1332-8.

7. Gray A, Smith C. Fitness, dietary intake, and body mass index in urban Native American youth. J Am Diet Assoc. 2003 Sep;103(9):1187-91.
8. Barlow SE, Dietz WH. Obesity evaluation and treatment: expert committee recommendations. Pediatrics. 1998 Sep;102(3):e29.

9. Nicklas T, Johnson R; American Dietetic Association (ADA). Position of the American Dietetic Association: Dietary guidance for healthy children ages 2 to 11 years. J Am Diet Assoc. 2004 Apr;104(4):660-77. Erratum in: J Am Diet Assoc. 2004 Jul;104(7):1075.

10. Savva SC, Kourides Y, Tornaritis M, Epiphaniou-Savva M, Chadjigeorgiou C, Kafatos A. Obesity in children and adolescents in Cyprus: prevalence and predisposing factors. Int J Obes Relat Metab Disord. 2002 Aug;26(8):1036-45

11. Lamerz A, Kuepper-Nybelen J, Wehle C, Bruning N, Trost-Brinkhues $\mathrm{G}$, Brenner H, et al. Social class, parental education, and obesity prevalence in a study of six-year old children in Germany. Int J Obes. 2005 Apr;29(4):373-80.

12. Ogden CL, Flegal KM, Carroll MD, Johnson CL. Prevalence and trends in overweight among US children and adolescents, 1999-2000. JAMA. 2002 Oct 9;288(14):1728-32.

13. Rolland-Cachera MF, Castetbon K, Arnault N, Bellisle F, Romano MC, Lehingue Y, et al. Body mass index in 7-9-y-old French children: frequency of obesity, overweight and thinness. Int J Obes Relat Metab Disord. 2002 Dec;26(12):1610-6.

14. Kromeyer-Hauschild K, Zellner K, Jaeger U, Hoyer H. Prevalence of overweight and obesity among school children in Jena (Germany). Int J Obes Relat Metab Disord. 1999 Nov;23(11):1143-50.

15. Lissau I, Overpeck MD, Ruan WJ, Due P, Holstein BE, Hediger ML; Health Behaviour in School-aged Children Obesity Working Group. Body mass index and overweight in adolescents in 13 European countries, Israel, and the United States. Arch Pediatr Adolesc Med. 2004 Jan;158(1):27-33.

16. Kobzová J, Vignerová J, Bláha P, Krejčovský L, Riedlová J. The $6^{\text {th }}$ nationwide anthropological survey of children and adolescents in the Czech Republic in 2001. Cent Eur J Public Health. 2004 Sep;12(3):126-30.

17. Kovářová M, Vignerová J, Bláha P, Ošancová K. Bodily characteristics and lifestyle of Czech children aged 7.00-10.99 years, incidence of childhood obesity. Cent Eur J Public Health. 2002 Dec;10(4):169-73.

18. Filiberti R, Kubík A, Reissigová J, Merlo F, Bonassi S. Cancer, cardiovascular mortality, and diet in Italy and the Czech Republic. Neoplasma. 1995;42(5):275-83.

19. Šoltysová T, Bellisle F. Nutrition in ten-year old children of the Liberec area (Czech Republic). Ann Nutr Metab. 1994;38(3):152-7.

20. Pařízková J. Dietary habits and nutritional status in adolescents in Central and Eastern Europe. Eur J Clin Nutr. 2000 Mar;54 Suppl 1:S36-40.

21. Humeníková L. Western influences on dietary intake in the post-communist Czech Republic [masters thesis]. Stillwater: Oklahoma State University; 2003.

22. Portney LG, Watkins MP. Foundations of clinical research: applications to practice. $2^{\text {nd }}$ ed. Upper Saddle River: Prentice Hall; 2000.

23. Moshfegb A, Borrud L, Perloff B, LaComb R. Improved method for the 24-hour dietary recall use in national surveys. FASEB J. 1999;13(4): A603.

24. Sallis JF, Strikmiller PK, Harsha DW, Feldman HA, Ehlinger S, Stone EJ, et al. Validation of interviewer- and self-administered physical activity checklists for fifth grade students. Med Sci Sports Exerc. 1996 Jul;28(7):840-51.

25. Johnson RK, Driscoll P, Goran MI. Comparison of multiple-pass 24-hour recall estimates of energy intake with total energy expenditure determined by the doubly labeled water method in young children. J Am Diet Assoc. 1996 Nov;96(11):1140-4.

26. Center for Nutrition Policy and Promotion [hompage on the Internet] MyPyramid. Washington, D.C.: United States Department of Agriculture [updated 2006 Nov 13; cited 2006 Nov 21]. Available from: http://www. cnpp.usda.gov.

27. Cullen KW, Baranowski T, Baranowski J, Hebert D, de Moor C. Behavioral and epidemiological coding of fruit and vegetable consumption from 24-hour dietary recalls: research question guides choices. J Am Diet Assoc. 1999 Jul;99(7):849-51.

28. Society for Nutrition. Czech dietary recommendations. Prague: Society for Nutrition; 1989. (In Czech.)

29. Dietary Reference Intakes. Dietary Reference Intakes for Energy, Carbohydrate, Fiber, Fat, Fatty Acids, Cholesterol, Protein, and Amino Acids. Panel on Macronutrients. National Academy of Sciences. Institute of Medicine of the National Academies. Washington, D.C.: The National Academies Press; 2002. 
30. Ainsworth BE, Haskell WL, Whitt MC, Irwin ML, Swartz AM, Strath SJ, et al. Compedium of Physical Activities: an update of activity codes and MET intensities. Med and Sci Sports and Exerc. 2000 Sep;32(9 Suppl): S498-504.

31. Lhotská L, Bláha P, Vignerová J, Roth Z, Prokopec M. The 5th nationwide anthropological survey of children and adolescents 1991, Czech Republic, Anthropometric characteristics. Prague: National Institute of Public Health; 1993. (In Czech.)

32. Kuczmarski RJ, Ogden CL, Grummer-Strawn LM, Flegal KM, Guo SS, Wei R, et al. CDC growth charts: United States. Adv Data. 2000 Jun 8; (314):1-27.

33. Zajka G. Dietary intake in Hungarian adolescents. Nutrition and Adolescence. Proceedings of European Academy of Nutritional Sciences Symposium; 1998 Oct; Madrid, Spain.

34. Center for Nutrition Policy and Promotion [homepage on the Internet]. Dietary Guidelines for Americans 2005. Washington, D.C.: United States Department of Agriculture [updated 2006 Nov 13; cited 2006 Nov 21]. Available from: http://www.cnpp.usda.gov.
35. Anděl M. Nutritional epidemiology in the Czech Republic after the fall of communism: problems with interpretation. Nutrition. 1997 NovDec;13(11-12):1008-9.

36. Martinchik AN, Baturin AK, Helsing E. Nutrition monitoring of Russian schoolchildren in a period of economic change: a World Health Organization multicenter survey, 1992-1995. Am J Clin Nutr. 1997 Apr;65(4 Suppl):S1215-9.

37. Andersen RE, Crespo CJ, Barlett SJ, Cheskin LJ, Pratt M. Relationship of physical activity and television watching with body weight and level of fatness among children: results from the Third National Health and Nutrition Examination Survey. JAMA. 1998 Mar 25;279(12):938-42.

Received September 13, 2006 Received in revised form and accepted November 21, 2006 